\title{
Wealth Effects and the Consumption of Leisure: Retirement Decisions During the Stock Market Boom of the $1990 \mathrm{~s}$
}

\author{
Julia Lynn Coronado \\ Federal Reserve Board \\ Washington, DC 20551 \\ 202-452-3044 \\ icoronado@frb.gov \\ Maria Perozek \\ Federal Reserve Board \\ Washington, DC 20551 \\ 202-452-2692 \\ mperozek@frb.gov
}

May 2003

\begin{abstract}
It is well accepted that households increase consumption of goods and services in response to an unexpected increase in wealth. Consensus estimates of this wealth effect are in the range of 3 to 5 cents of additional consumption spending in the long run for each additional dollar of wealth. Economic theory also suggests that consumption of leisure, like consumption of goods and services, should increase with positive shocks to wealth. In this paper, we ask whether the run-up in equity prices during the 1990s led older workers to retire earlier than they had previously planned. We identify the effect by exploiting unique data on retirement expectations from the Health and Retirement Survey (HRS). Our econometric results suggest that respondents who held corporate equity immediately prior to the bull market of the 1990s retired, on average, 7 months earlier than other respondents.

We would like to thank Len Burman, Karen Dynan, William Gale, Andreas Lehnert, Michael Palumbo, Jonathan Parker, and William Wascher for helpful comments on an earlier draft. We are grateful to Jennifer Hohmann and Carlos Manzanares for excellent research assistance. The views expressed in this paper are those of the authors and do not necessarily reflect the views of the Federal Reserve Board or its staff.
\end{abstract}




\section{$\underline{\text { Introduction }}$}

Between 1990 and 1999, the S\&P 500 stock index appreciated an average of about 15 percent per year--more than twice its average pace over the previous 40 years. The unusual strength in the stock market likely took many investors by surprise as they watched their wealth balloon over the last half of the 1990s. The unexpected and prolonged nature of this stock market boom provides a unique opportunity to measure how gains in stock market wealth affect household behavior. Life-cycle theory predicts that people will boost their consumption of goods and services as well as leisure in response to unanticipated increases in their wealth. Recent research indicates that a dollar increase in wealth raises the consumption of goods and services by between 3 cents and 5 cents.

Most studies have focused on measuring the effect of wealth shocks on the consumption of goods and services, ignoring any effects on the consumption of leisure. In this paper, we ask how the unexpected stock market gains of the 1990s affected the consumption of leisure--in particular, whether the stock market boom led older workers to retire earlier than they had previously planned. We focus on the retirement decision for three reasons: First, because institutional constraints limit the ability of workers to adjust their leisure response at the margin, it is possible that much of the leisure response to wealth shocks will involve adjusting the timing of retirement decisions. Second, it is typically difficult to identify wealth effects on the consumption of both goods and leisure because standard economic theory implies that wealth and consumption decisions are simultaneously determined. However, we are able to sidestep many of the usual identification problems by using unique data on retirement expectations for a cohort of those nearing retirement just prior to the massive run-up in stock prices. We identify the wealth effect by looking at how actual retirement outcomes differ from pre-bull market expectations. Finally, workers who are nearing retirement age are typically hitting their peak net worth years, and therefore the cohort nearing retirement in the early 1990s was most likely to reap the largest unexpected gains in their stock portfolios.

\footnotetext{
${ }^{1}$ Poterba (2000) provides a useful survey of the literature on wealth effects; more recent examples include Dynan and Maki (2001), Juster, et. al. (2001), and Maki and Palumbo (2001).
} 
Incorporating wealth effects on leisure may help to reconcile life-cycle theory with the fact that, under the assumption of a 3 percent after-tax interest rate, consensus estimates of the wealth effect imply that people will not eventually consume all their wealth (Cheng and French, 2000). Although it is possible that this behavior can be rationalized in a life-cycle framework by the existence of bequest motives and/or incomplete insurance markets, it is equally plausible that some of the unexpected increase in wealth is used to finance an increase in the consumption of leisure.

\section{$\underline{\text { Previous Literature }}$}

Our paper contributes to a small but growing literature on the effects of wealth on labor supply. ${ }^{2}$ Earlier work focused mainly on the effects of inheritances and lottery winnings as sources of unanticipated wealth shocks. For example, Holtz-Eakin, Joulfaian and Rosen (1993) provided evidence that large inheritances reduce the labor supply of recipients, while Joulfaian and Wilhelm (1994) found only modest negative disincentive effects of inheritances on labor supply. Although inheritances may or may not constitute unexpected increases in wealth, the negative effects on labor supply suggest that at least part of the inheritance was unexpected. In addition, Imbens, Rubin and Sacerdote (2001) found that winners of large lottery prizes significantly reduced both their labor force participation and hours worked.

More recently, the literature has focused on the effect of the 1990s stock market boom on the labor force participation of older workers. Cheng and French (2000) estimated that the stock market run-up of the 1990s reduced the labor force participation of older men by between 1 and 3-1/4 percentage points, on average, between 1995 and 1999. Sevak (2001) found that early retirement rates for workers with DC pension plans rose relative to the early retirement rates of other workers, which remained stable between 1992 and 1998. Taken together, these findings suggest that large positive wealth shocks can reduce labor supply.

Finally, there are two recent papers that have also exploited data on retirement expectations to identify wealth effects on retirement. Hurd and Reti (2001) found little

\footnotetext{
${ }^{2}$ There is a large literature on other aspects of retirement behavior, particularly on the effects of pensions on retirement. For example, see Gustman and Steinmeier (1986), Stock and Wise (1990), Rust and Phelan (1997), Samwick (1998), Coile and Gruber (2000), and Chan and Stevens (2001).
} 
effect of wealth on subjective probabilities of working full time after age 62. However, to the extent that most of the earlier-than-expected retirement takes place well-before or after age 62, the probability of working past 62 might not be significantly revised. Khitatrakun (2001) explored the determinants of changes in retirement expectations in consecutive waves of the HRS, with a focus on the effect of stock ownership and changes in wealth. Although the econometric specification was quite different from ours (described below), Khitatrakun also found that respondents who held large amounts of stocks retired earlier than expected relative to other respondents.

$\underline{\text { Retirement decisions in a life-cycle framework with health and investment risk }}$

This section describes a simple life-cycle framework for thinking about retirement behavior in the presence of uncertainty about future economic status as well as uncertainty about family and individual characteristics such as health and marital status. Life-cycle models predict that individuals will work and accumulate assets while young and middle-aged, and retire and draw down assets when old. If there is no uncertainty, life-cycle consumers will never find it optimal to deviate from the retirement age and consumption path chosen at the beginning of their lives.

In reality, consumers face uncertainty regarding the outcomes of economic variables such as future income and investment returns, as well as individual and family characteristics such as health status and marital status. Individuals must make retirement plans and consumption decisions that maximize their expected utility based on their best guess about future realizations of uncertain variables. We can characterize the formation of retirement expectations $\left(\mathrm{R}^{E}\right)$ by the following equation:

$$
R_{t}^{E}=E\left(R \mid A_{t}, y_{t}, Z_{t}\right)
$$

where $\mathrm{R}$ is the year of expected retirement, $\mathrm{A}$ is net worth, $\mathrm{y}$ is income and $\mathrm{Z}$ is a vector of personal and family characteristics such as marital status and health status.

As time goes by, some uncertainty about investment returns, health status and family status is resolved. For example, one year after forming initial retirement expectations, the consumer will have observed the realizations of health status, family 
composition, and investment returns over the course of that year. To the extent that these realizations differ from previous expectations, workers will re-optimize and update their expectations about their retirement age and consumption path accordingly.

The difference between retirement expectations at any two points in time (say, time $t$ and $t+\Delta)$ is a function of variables at the initial point in time $(t)$ and unexpected changes in those variables over that period ( $t$ to $t+\Delta$ ). According to this theory, only unexpected changes should alter the optimal retirement path. However, it is likely that individuals with different personal characteristics at the outset will respond differently to unexpected changes in the relevant variables. For example, those with larger initial levels of wealth may revise their expected retirement dates down by more in the event of a health shock than those with lower levels of initial wealth. As a result, individuals with different observable characteristics at time t may update their expectations differently in response to similar shocks to wealth, health or other variables. That is, retirement expectations $\left(\mathrm{R}^{E}\right)$ are updated for each worker according to equation (2):

(2) $\mathrm{R}_{\mathrm{t}+\Delta}^{E}=\mathrm{E}\left(\mathrm{R} \mid \mathrm{R}_{\mathrm{t}}^{E}, \Delta \mathrm{A}, \Delta \mathrm{y}, \Delta \mathrm{Z}, \mathrm{A}_{\mathrm{t}}, \mathrm{y}_{\mathrm{t}}, \mathrm{Z}_{\mathrm{t}}\right)$

where

$$
\begin{aligned}
& \Delta \mathrm{A}=\mathrm{A}_{\mathrm{t}+\Delta}-\mathrm{E}_{\mathrm{t}}\left[\mathrm{A}_{\mathrm{t}+\Delta}\right] \\
& \Delta y=\mathrm{y}_{\mathrm{t}+\Delta}-\mathrm{E}_{\mathrm{t}}\left[\mathrm{y}_{\mathrm{t}+\Delta}\right] \\
& \Delta \mathrm{Z}=\mathrm{Z}_{\mathrm{t}+\Delta}-\mathrm{E}_{\mathrm{t}}\left[\mathrm{Z}_{\mathrm{t}+\Delta}\right]
\end{aligned}
$$

In sum, workers update their retirement expectations in response to unexpected changes in wealth, health and other variables. Hence, if wealth grew at a faster-thanexpected rate between time $t$ and $t+\Delta$, i.e., $A_{t+\Delta, i}>E_{t}\left[A_{t+\Delta, i}\right]$, then the expected date 
of retirement $\left(\mathrm{R}_{i}^{E}\right)$ would be revised down, ceteris paribus. That is, there is a wealth effect on planned retirement age given by $\frac{\partial R_{i}^{E}}{\partial \Delta \mathrm{A}_{\mathrm{i}}}<0$.

\section{Identifying the Effects of Wealth Shocks on Retirement Decisions}

As a practical matter, identifying the effect of wealth on retirement decisions is difficult because the level of wealth and the decision to retire are simultaneously determined. For example, individuals who have strong preferences for leisure may opt to save more and accumulate more wealth while young in order to facilitate earlier retirement from the labor force. Our empirical strategy escapes this identification pitfall by exploiting unique data available from the Health and Retirement Study (HRS) on retirement expectations just prior to the period of extraordinary, and arguably unanticipated, stock market returns in the 1990s. By conditioning on a priori expectations, and treating the extra-normal returns as unexpected, we can identify the response to a wealth shock by measuring the degree to which the actual retirement decisions of those with exposure to the stock market deviate from their pre-bull market expectations.

\section{Data: The Health and Retirement Study}

The HRS is a panel data set that provides detailed information on the health and economic status, as well as work histories of a nationally representative cohort of people who were between 51 and 61 years old in 1992 and their spouses. These individuals and their spouses are re-interviewed every two years. We use data from the first five waves of the HRS (1992, 1994, 1996, 1998 and 2000), allowing us to capture virtually all of the stock market run-up that occurred from the mid-1990s through the first quarter of 2000. We select a sample of respondents who were in the labor force at the initial interview in 1992.

\footnotetext{
${ }^{3}$ It is possible that some respondents altered their investment returns expectations during the stock market boom and anticipated double-digit returns in the future. If this were the case then, in addition to the wealth effect, there would be a substitution effect where respondents delayed retirement in order to continue pumping savings into equity markets. The issue of which effect dominates will be resolved empirically. ${ }^{4}$ We include spouses of age-eligible respondents in our sample, who may be younger or older than the ageeligible cohort. In addition, we limit the sample to workers who are between 45 and 65 years old in 1992.
} 
Our strategy for identifying the retirement wealth effect relies on measuring retirement expectations at the initial HRS interview in 1992. Respondents who were in the labor force were asked in what year they expected to retire completely. In theory, if retirement expectations were rational, they would reflect all relevant information available to respondents in 1992 as well as the subjective probability distributions of events, such as health and wealth shocks, that might influence labor force decisions. 5 . A recent study by Benitez-Silva and Dwyer (2002) shows that the retirement expectations of HRS respondents vary in reasonable ways with personal and family characteristics, including the level of wealth, health status and marital status. Moreover, they find that retirement expectations are rational in the sense that they follow a random walk; that is, baseline characteristics are no longer significant predictors of expectations after controlling for previous-period expectations.

\section{$\underline{\text { Retirement patterns in the HRS }}$}

As the HRS follows people through time, we can observe whether individuals actually retired earlier or later than they had anticipated. The top panel of figure 1 shows the distribution of expected retirement ages for our sample. Most of the sample had expected to retire between the ages of 60 and 67, with spikes at ages 62 and 65. Turning to actual retirement decisions, the middle panel shows the distribution of retirement ages for those who retired before the fifth wave, accounting for about 43 percent of the sample. The bottom panel reports deviations from expected retirement for those who retired; calculated as the actual age of retirement less the expected age of retirement. If an individual retired earlier than expected, the deviation will be negative. Among those

\footnotetext{
${ }^{5}$ For instance, workers in poor health may foresee further health problems in the future, and consequently plan to retire earlier than workers who are in better health. Alternatively, the value of leisure might be greater for someone in better health, leading them to retire earlier. Empirical analysis is therefore necessary to determine the effect of health on retirement. In any case, the health status at baseline will be factored into retirement expectations.

${ }^{6}$ Using data from the Retirement History Survey--the precursor to the HRS--Bernheim (1989) examines the accuracy of retirement expectations between 1969-1975 and finds that consumers form reasonably accurate expectations about retirement, although the accuracy of these expectations tends to vary by gender, marital status and wealth. However, Bernheim does not consider the effects of uncertainty in health status or investment returns on deviations from expected retirement dates. It is likely that shocks to both health and wealth affect behavior differently by gender, marital status and wealth.
} 
who retired, more than half retired earlier than expected, somewhat less than a quarter retired as expected, and about a fifth retired later than expected.

If actual retirement dates deviate from expectations, we can explore whether these deviations are related to changes in the fundamental economic and family/individual characteristics on which expectations were based in 1992. If expectations in 1992 about future stock market returns were based on historical experience, then those holding stock likely experienced unexpectedly large gains on their stock portfolios from 1995 through 2000. The positive shock to the wealth of stockholders might have induced some of these individuals to retire earlier than they expected at the 1992 baseline interview.

Of course, other personal characteristics may also have affected retirement decisions. Thus, in our econometric analysis, we include health status at the baseline and shocks to health over the survey period, as well as marital status at the baseline and changes in marital status, which may or may not have been anticipated at the time of the initial interview. In addition, we control for employer-provided benefits such as early retirement incentives and pensions, which are important components of wealth and likely affect both retirement plans and an individual's response to financial and health shocks. Other variables included in the specification include age, years to expected retirement, education, gender, and whether the respondent was self-employed.

\section{Descriptive Statistics}

Table 1 presents selected descriptive statistics for the HRS sample calculated separately by retirement status in 2000 . Among those who retired before 2000 , the sample is split further according to their retirement date, i.e. in or before 1996 or after 1996, and according to whether they retired earlier than they had expected, or on time to

later than expected. ${ }^{\square}$ If shocks to wealth from the stock-market run-up induced respondents to retire early, we would expect to see a relationship between stock market wealth and early retirement only for the group of people who retired after 1996--that is, after at least two years of outsized stock market gains. It seems reasonable to expect that the factors underlying exits from the labor force might be somewhat different among those who retired prior to 1997, and that those who retired earlier than they had expected

\footnotetext{
${ }^{7}$ A complete description of the variables and descriptive statistics are presented in the data appendix.
} 
during that period might have been influenced by other factors such as health shocks and employer-provided incentives for early retirement. For simplicity, we will henceforth refer to those who retired earlier than they had expected as "early" retirees, and others as "on time or late" retirees.

The first set of variables summarizes the demographic characteristics of the sample. In general, those who retired early tended to be younger than other retirees but older than respondents who were still working in 2000. In addition, more of the "early" retirees were female, especially during the first half of the sample period--perhaps indicating that women make larger adjustments to their labor supply in response to unexpected changes in their economic or health status.

The second panel presents the mean economic characteristics of the sample. Among those who retired between 1993 and 1996, early retirees were less likely to have held stock at the baseline interview (65.5 percent vs. 71.7 percent), but on average, held similar levels of stock market wealth and net worth as their counterparts who retired on time or later than expected. For sample members retiring between 1997 and 2000, rates of stockownership for early retirees were also lower than other retirees (though not significantly so. However, early retirees held, on average, greater amounts of stock market wealth, and their stock holdings represented a larger fraction of their financial assets in 1992. In particular, early retirees held 31.7 percent of their financial assets in stock in 1992 compared with 28.8 percent held by other retirees. These data illustrate that higher levels of stock exposure appear to be associated with early exits from the labor force only for those respondents who retired in the latter half of the sample period after multiple years of unusually high stock market returns.

The data also indicate that those who retired earlier than expected were less likely than other retirees to be covered by a defined-benefit (DB) pension plan. In particular, only 42 percent of the early retirees in both periods had DB plans, compared with about 36 percent of those who did not retire, and 59 and 52 percent of others who retired before and after 1996, respectively. This is not surprising, as the eligibility rules for DB plans may effectively dictate the date of retirement; therefore, the labor supply of those with DB plans may be less elastic with respect to unexpected changes in economic and health status relative to other workers who are not subject to DB plan constraints. 
The third panel of the table presents several indicators of baseline health status and health shocks experienced over the survey period. Sample members who retired early in both the first and the second half of the sample period were more likely to be in fair or poor health in 1992 (17 percent in first half, 11.3 percent in second half) than other retirees (12.6 percent in the first half, 5.2 percent in the second half) or nonretirees (7.6 percent). In addition, early retirees between 1993 and 1996 were more likely to experience "negative" health shocks early in the sample period, perhaps suggesting that health shocks are associated with early retirement over this period. In contrast, for those who retired after 1996, there is no significant difference in the prevalence of early health shocks or health shocks that occurred at any time over the survey period between early retirees and other retirees. The higher incidence of poor health and health shocks among the early retirees in the first half of the survey period suggests that poor health combined with further deterioration in health may have played a relatively more important role in earlier-than-expected exits from the labor force for those who retired early in the first part of the survey period than for those who retired in the late 1990s.

The data also indicate that employer-provided health insurance benefits are related to retirement behavior. Early retirees in both sample periods were somewhat less likely to be covered by employer-provided health insurance from their own jobs, especially those who retired between 1993 and 1996. However, early retirees were significantly more likely to have access to employer-provided health insurance through their spouse, and were therefore less tied to the labor force for health insurance purposes. Access to retiree health insurance also varies somewhat by retirement status and timing. Depending on the age of the respondent and the eligibility requirements of the plan, the availability of retiree health insurance may induce individuals to work longer or retire earlier. In our sample, the results are mixed. Among those who retired in the first half of the sample period, about 60 percent of the early retirees had access to retiree health insurance compared with 68 percent of other retirees; there is no significant difference among those who retired later in the sample period.

These descriptive statistics suggest that there may be important relationships between shocks to health and wealth and decisions to retire earlier than expected. In particular, they suggest that wealth shocks in the latter part of the 1990s may have 
induced early exits from the labor force. However, in order to identify the effects of wealth shocks on deviations from retirement expectations, it is necessary to control for other relevant variables in a regression framework.

\section{Econometric Specification}

According to equation (2), the degree to which actual retirement dates differ from expected retirement dates should be a function of changes in variables that could not be predicted with certainty at the baseline, such as wealth, health status and family structure. Also, as noted above, individuals with different baseline characteristics are likely to vary in their reaction to unexpected changes in these variables. To identify the determinants of deviations from expected retirement, we estimate the following equation:

$$
\begin{aligned}
& R_{i}^{*}-R_{i}^{E}=\beta_{0}+\beta_{1} \Delta A_{i}+\beta_{2}^{\prime} \Delta Z_{i}+\beta_{3} A_{i}+\beta_{4}^{\prime} Z_{i}+\varepsilon_{i} \\
& \text { where } \quad R_{i}^{*}-R_{i}^{E}=\left\{\begin{array}{l}
R_{i}^{*}-R_{i}^{E} \text { if } R_{i}^{*} \leq 2000 \\
2000-R_{i}^{E} \text { if } R_{i}^{*}>2000
\end{array}\right.
\end{aligned}
$$

where $i$ indexes individuals in the sample and $\mathrm{R}^{*}$ is the year of actual retirement. If an individual has retired before 2000 (the fifth HRS wave), then we observe the actual deviation from expected retirement denoted by $R_{i}^{*}-R_{i}^{E}$. Otherwise, if the individual has not retired by 2000 , we know that the actual deviation $R_{i}^{*}-R_{i}^{E}$ is greater than the censored value $2000-R_{i}^{E}$; that is, for respondents who are still working in 2000 , the deviation from expected retirement is right-censored. Because expectations of retirement vary across the sample, the dependent variable for non-retirees is right-censored at different points for different respondents. As a result, we use censored normal regression to estimate the parameters in equation $\left(2^{\prime}\right)$.

Capturing unanticipated gains on stock market wealth in the HRS is not clear cut. Although stock market wealth is measured across waves, some respondents are surely transitioning into retirement and reallocating their portfolios. Thus, to estimate the total effect of stock market gains on retirement, we include both a dummy for stock ownership in 1992 and a constructed variable that stands in for the unanticipated gain in stock 
market wealth for each household. The proxy variable for the unanticipated gain is equal to the value of stock in 1992 multiplied by the difference between the appreciation in the Wilshire 5000 stock index over this period and 8 percent per year--the return that investors may have expected based on historical experience. (Cheng and French, 2000).

While baseline characteristics are important determinants of retirement expectations, they can also influence deviations from expected retirement in at least two ways. First, the accuracy of expectations may differ systematically by baseline characteristics. For example, Bernheim (1989) finds evidence that men form more accurate retirement expectations than women, and that married women, in particular, tend to underestimate how long they will work. Second, unexpected changes, such as health shocks, may affect people differently depending on their baseline characteristics. For example, workers who were in poor health in 1992 may be more likely to leave the labor force following a health shock than those who were in excellent health in 1992.

Several issues arise in estimating equation $\left(2^{\prime}\right)$. First, theory predicts that only unanticipated changes in relevant socio-economic variables should alter expectations about retirement, while in reality, we observe only the total change in the relevant variable; we cannot decompose that change into its anticipated and unanticipated components. However, if most changes in wealth were anticipated, then the data will not exhibit the variation necessary to identify $\beta_{1}$. Conversely, if $\beta_{1}$ is found to be economically and statistically significant, then it is likely that part of the change in wealth was unexpected, although this estimate of $\beta_{1}$ will understate the actual effect of unanticipated wealth changes on retirement decisions.

Second, the accuracy of retirement predictions varies systematically by the length of time before expected retirement; in particular, the variance of deviations from expectations increases as the horizon length increases. This is not surprising in light of the number of uncertainties that are resolved over time--it is nearly always easier to forecast an expected retirement next year than it is to accurately predict the exact date 10 years hence. To correct for the heteroskedasticity of the errors in equation ( $\left.2^{\prime}\right)$, we weight the observations in the regression by the number of years to expected retirement.

Finally, although it is intuitively appealing to use deviations from expectations as the dependent variable in our econometric specification, we can also view equation $\left(2^{\prime}\right)$ 
as a special case of a more general specification in which the dependent variable is the actual retirement date if retired and the censored value if not retired, and the expected retirement date (in 1992) is an explanatory variable. In this more general set-up, the special case given by equation $\left(2^{\prime}\right)$ would derive from constraining the coefficient on expected retirement date to one. In the next section, we present results from both specifications.

\section{$\underline{\text { Results }}$}

The first column of table 2 presents marginal effects for selected explanatory variables from the censored normal regression model where the dependent variable is the deviation from retirement expectations, calculated as the actual retirement age less the

expected retirement age. ${ }^{\text {B }}$ As noted above, if a respondent is not retired, their deviation is right-censored at the value 2000 less the expected retirement age.

The first two rows of the table present the effects of stock-ownership on deviations from retirement expectations. The estimates suggest that, on average, those who held stock retired about 3 months ( .24 years) earlier than they had previously expected relative to nonstockholders. Conditional on being a stockholder in 1992, higher levels of stock exposure also increase the likelihood of early exits from the labor force: An additional \$100,000 in unexpected stock market gains, led respondents to retire 2 weeks earlier than expected. Therefore, the average stockholder--who received roughly $\$ 100,000$ in unanticipated gains--retired 3-1/2 months ahead of expectations.

As noted above, equation $\left(2^{\prime}\right)$ is a special case of a more general specification in which the actual retirement year is the dependent variable (right censored at 2001 for those who have not yet retired) and the expected date of retirement is an independent variable. The marginal effects from this more general specification, which are presented in the second column of table 2 , are quite different from the first specification, suggesting that it was inappropriate to constrain the coefficient on the expected date of retirement to equal 1. Although the point estimates vary noticeably between the two specifications, the effects do not change sign and are statistically significant at about the same level. While the qualitative story from this specification is similar, the magnitude of the marginal

\footnotetext{
${ }^{8}$ Marginal effects for the all of the explanatory variables are included in the appendix.
} 
effect of stock ownership on retirement behavior is about twice as large. In this specification, conditional on expectations, the average stockholder retires almost 7 months earlier than expected relative to nonstockholders. Because the more general specification is more flexible and the fit is much better (Pseudo-R-squared of .17 vs. .06), we focus on the more general specification from this point forward.

As shown in lines 3 and 4, those with greater net worth in 1992 retired a bit earlier than others, perhaps as a result of their ability to afford retirement given changes in economic or health variables. Similarly, those with DB plans (shown in line 5) retired 10-1/2 months earlier than those without DB plans, even controlling for employer offers of early-retirement incentives. This result may be somewhat surprising given the descriptive statistics presented above; however, recall that nonretirees as a group were least likely to have DB plans, perhaps reflecting less exposure to the type of early retirement incentives embedded in some DB plans. In addition, the finding that DB plans are associated with early exits from the labor force may represent a wealth effect of sorts that occurs if better information about the magnitude of DB pension wealth is revealed as one approaches retirement.

It is interesting to note that respondents who were self-employed in 1992 worked quite a bit longer than wage and salary workers (1 year and 5 months). In a separate specification discussed below, we further explore the differences between self-employed and wage and salary workers.

As shown in the bottom half of the table, we also control for changes in health status, which may not have been fully anticipated by the respondent at the time of the initial interview in 1992. In particular, those who were diagnosed with cancer, stroke, heart disease or lung disease between 1992 and 1994 retired about 7 months earlier than those who were never diagnosed with these conditions. Broadly speaking, those who were in better health in 1992 tended to work between 1 and 1-1/2 years longer than those who reported that they were in poor health in 1992.

As the descriptive statistics suggested, health insurance coverage is an important determinant of deviations from retirement plans. Those with employer provided health insurance but not retiree health insurance worked 1 year and 1 month longer than those 
with no employer-provided coverage at all. ${ }^{9}$ However, those with both employerprovided health insurance and retiree health insurance retired about 1 year earlier than those with just employer-provided health insurance. On net, the effect of employerprovided coverage appears to be a small positive, as the positive effects of the health insurance coverage outweigh the negative effects of the retiree health insurance coverage.

Responses to shocks may vary by personal characteristics. In particular, men and women in this cohort may have fundamentally different retirement decision functions, and may therefore react quite differently in the event of a shock to their health or wealth. To investigate this possibility, table 3 presents marginal effects from the generalized version of equation (2') estimated separately for men and women.

Although the effects of stock on retirement are substantial for both men and women, the marginal effects for the two variables representing stock ownership and unanticipated gains--shown in the first two rows of the table--are quite different. In particular, the marginal effect of stock-ownership for women is 2-1/2 times larger in absolute value than the marginal effect for men, while the marginal effect for unanticipated gain for women is roughly one-fifth the magnitude of the effect for men. On net, stock ownership appears to have larger effects on the retirement decisions of women. Assuming a $\$ 100,000$ unanticipated gain on stock, female stockholders retired about 8 months earlier than other women, while male stockholders retired just over 5 months earlier than other men. These results may reflect the likelihood that women in this cohort represent the marginal worker in the family, and as such, may be more likely to adjust their labor force participation in response to unanticipated stock market gains than men.

In addition, women appear to be less sensitive to employer-provided benefits such as health insurance and pensions. As shown in row 4, men with defined benefit pension plans leave the labor force 14 months earlier than men who were not covered by a DB plan, while the marginal effect for women is only half as large. Also, the effects of having employer-provided health insurance and retiree health insurance are smaller in absolute value for women.

\footnotetext{
${ }^{9}$ Coefficient estimates are presented only for employer-provided health insurance covering self only; coefficient estimates for other employer-provided health insurance variables are similar (reported in the appendix).
} 
We have abstracted from the joint decision making process that likely influences expected and actual retirement dates for couples and treated changes in spouses' economic status and health as exogenous. Although not presented here in detail, our results indicate that a spouse's decision to retire during the sample period is associated with earlier retirement, and for women, a spouse's deteriorating health is associated with early exits from the labor force.

There is evidence that entrepreneurs--or self-employed respondents--may behave quite differently from wage and salary workers. In table 4, we explore whether retirement decisions also vary by self-employment status. As shown in the first two rows, the marginal effects of the stock market variables are much larger in absolute value for the self-employed (shown in column 2) than for the wage and salary workers (shown in column 1). Given a $\$ 100,000$ unanticipated gain, self-employed stockholders leave the labor force more than a year earlier than other self-employed workers, while wage and salary stockholders exit the labor force 6 months earlier than their non-stockholding counterparts.

The effect of initial wealth also varies substantially by self-employment status. Among wage and salary workers, those with an extra $\$ 100,000$ in initial wealth left the labor force 2 months earlier, but among the self-employed, an additional \$100,000 in wealth is associated with a 1 month longer stay in the labor force. While having a DB pension is associated with early retirements for both groups, the effect is more dramatic for the self-employed, who exited the labor force 3-1/4 years ahead of non-covered selfemployed workers, ceteris paribus.

Although some of the most difficult identification problems are addressed in this paper through the use of retirement expectations, there are still a few potential endogeneity problems that remain. In particular, the estimates of the wealth effect found in this paper might be biased if unobservable characteristics are correlated with both stock ownership and a willingness to revise retirement plans. For example, lower levels of risk aversion might be correlated with increased exposure to stock as well as an increased willingness to alter retirement behavior in the event of a shock.

We can investigate whether risk aversion is associated with stock holding and retirement behavior in the HRS by looking at rates of stock ownership and early 
retirement by respondents ranked according to their responses to a question that was designed to measure risk aversion. ${ }^{10}$ Table 5 shows rates of stock ownership and early retirement calculated by risk aversion category, where 1 denotes the least risk averse and 4 denotes the most risk averse. While rates of stock ownership, shown in line 1, are not significantly higher among the least risk averse, the average stock level, shown in line 2, is significantly higher, with the least risk averse group holding roughly $\$ 66,000$ in stock in 1992 compared with about $\$ 47,500$ held by the most risk averse group. However, as shown in line 3 , the percentage of financial assets held in stock does not vary substantially across risk-aversion categories. Moreover, there does not appear to be an increased propensity to retire early among the least risk averse group; in fact, rates of early retirement increase from 21 percent in the least risk averse group to 25 percent in the most risk averse group. Therefore, these data do not suggest that there is a systematic relationship between reported risk aversion and the propensity to both hold stocks and retire early in the HRS.

\section{$\underline{\text { Conclusion }}$}

The results of our analysis indicate that the bull market of the 1990s led to a wealth effect on the consumption of leisure. In particular, the average stockholder in our sample had an unanticipated stock market gain of about $\$ 100,000$, which led them to retire roughly 7 months earlier than nonstockholders.

Given the recent large and sustained declines in stock prices, we might expect older workers with exposure to the stock market to now be postponing their retirement, and retirees with equity holdings to be re-entering the workforce. As shown in figure 2, labor force participation rates for men aged 55 to 64 have indeed risen over the past two years as the stock market has plunged. 11

Our analysis indicates that unexpected changes in wealth influenced retirement behavior in a period that was characterized by high stock market returns and increasing household exposure to equities. If household exposure to stock market risk continues to

\footnotetext{
${ }^{10}$ See the data appendix for a more detailed description of the risk aversion measure.

${ }^{11}$ While we find that the retirement decisions of older women are more responsive to wealth shocks, it is hard to discern an effect in the aggregate data because of the strong upward trend in the labor force participation rates of older women.
} 
grow, then the labor force participation of older workers will likely become more sensitive to sustained moves in asset prices. As a result, the effect of wealth on retirement should continue to be an important issue in the ongoing debate about retirement security, especially in evaluating retirement policies that involve potentially raising households' equity exposure, such as recent proposals to add individual accounts to the social security system. 


\section{References}

Benitez-Silva, Hugo and Debra S. Dwyer. 2002. "Retirement Expectations Formation using the Health and Retirement Study." mimeo.

Bernheim, B. Douglas. 1989. The Timing of Retirement: A Comparison of Expectations and Realizations." in The Economics of Aging, David Wise. Chicago: University of Chicago Press.

Chan, Sewin and Ann Huff Stevens. 2001. "Retirement Incentives and Expectations." National Bureau of Economic Research Working Paper no. 8082 (January).

Cheng, Ing-Haw and Eric French. 2000. "The Effect of the Run-up in the Stock-Market on Labor Supply." Economic Perspectives (Fourth Quarter).

Coile, Courtney and Jonathan Gruber. 2000. "Social Security and Retirement." National Bureau of Economic Research Working Paper no. 7830 (August).

Dwyer, D.S. and O.S. Mitchell. 1999. "Health Shocks as Determinants of Retirement: Are Self-Rated Measures Endogenous?" Journal of Health Economics, 18:173193.

Dynan, Karen E. and Dean M. Maki. 2001. "Does Stock Market Wealth Matter for Consumption?" Federal Reserve Board Finance and Discussion Series working paper no 2001-23 (May).

Gustman, Alan L. and Thomas L. Steinmeier. 1986. "A Structural Retirement Model." Econometrica 54(3): 555-584.

Gustman, Alan L. and Thomas L. Steinmeier. 2000. "Retirement Outcomes in the Health and Retirement Study." National Bureau of Economic Research Working Paper no. 7588 (March).

Holtz-Eakin, Douglas, David Joulfaian, and Harvey S. Rosen, 1993. "The Carnegie Conjecture: Some Empirical Evidence.” The Quarterly Journal of Economics 108(2):413-35.

Hurd, Michael and Monika Reti. 2001. The Effects of Large Capital Gains on Work and Consumption: Evidence from Four Waves of the HRS." Department of Labor, Report \#J9P70045.

Imbens, Guido W., Donald B. Rubin and Bruce I. Sacerdote. 2001. "Estimating the Effect of Unearned Income on Labor Supply, Earnings, Savings, and Consumption: Evidence from a Survey of Lottery Players." The American Economic Review, 91(4):778-794. 
Khitatrakun, Surachai. 2001. "Wealth and the Timing of Retirement." mimeo.

Joulfaian, David and Mark O. Wilhelm. 1994. "Inheritance and Labor Supply." Journal of Human Resources, 29(4):1205-34.

Juster, F. Thomas, Joseph Lupton, James P. Smith, and Frank Stafford. 2001. "The Decline in Household Saving and the Wealth Effect." Manuscript, University of Michigan.

Maki, Dean M. and Michael Palumbo. 2001. "Disentangling the Wealth Effect: A Cohort Analysis of Household Saving in the 1990s." Federal Reserve Board Finance and Discussion Series working paper no 2001-21 (April).

Poterba, James M. 2000. "Stock Market Wealth and Consumption.” Journal of Economic Perspectives 14, no. 2(Spring): 99-118.

Rust, John and Christopher Phelan. 1997. "How Social Security and Medicare Affect Retirement Behavior in a World of Incomplete Markets." Econometrica 65(4):781-821.

Samwick, Andrew. 1998. "New Evidence on Pensions, Social Security and the Timing of Retirement." Journal of Public Economics 70(2):207-236.

Sevak, Purvi. 2001. "Wealth Shocks and Retirement Timing: Evidence from the Nineties." Unpublished manuscript, University of Michigan.

Stock, James and David Wise. 1990. "Pensions, the Option Value of Work, and Retirement." Econometrica 58:1151-1180. 


\section{Table 1: Means of Selected Variables by Timing of Retirement Relative to Expectations}

\begin{tabular}{|c|c|c|c|c|c|}
\hline & \multicolumn{2}{|c|}{ Retired between 1993 and 1996} & \multicolumn{2}{|c|}{ Retired between 1997 and 2000} & \multirow{2}{*}{$\begin{array}{c}\text { Not Retired } \\
-\end{array}$} \\
\hline & Early & On time or late & Early & On time or late & \\
\hline \multicolumn{6}{|l|}{ Demographic } \\
\hline Male $(\%)$ & $\begin{array}{l}48.3 \\
(2.0)\end{array}$ & $\begin{array}{l}55.1 \\
(2.5)\end{array}$ & $\begin{array}{l}50.7 \\
(2.7)\end{array}$ & $\begin{array}{l}53.4 \\
(2.5)\end{array}$ & $\begin{array}{l}46.6 \\
(1.0)\end{array}$ \\
\hline Married (\%) & $\begin{array}{l}81.9 \\
(1.6)\end{array}$ & $\begin{array}{l}85.2 \\
(1.8)\end{array}$ & $\begin{array}{l}83.5 \\
(2.0)\end{array}$ & $\begin{array}{l}82.1 \\
(1.9)\end{array}$ & $\begin{array}{l}83.1 \\
(0.8)\end{array}$ \\
\hline Age (years) & $\begin{array}{l}56.5 \\
(0.1)\end{array}$ & $\begin{array}{l}58.5 \\
(0.2)\end{array}$ & $\begin{array}{l}54.3 \\
(0.2)\end{array}$ & $\begin{array}{l}57.0 \\
(0.2)\end{array}$ & $\begin{array}{l}53.3 \\
(0.1)\end{array}$ \\
\hline $\begin{array}{l}\text { Retirement Age } \\
\text { Economic }\end{array}$ & $\begin{array}{l}58.9 \\
(0.1)\end{array}$ & $\begin{array}{l}61.2 \\
(0.2)\end{array}$ & $\begin{array}{l}60.4 \\
(0.2)\end{array}$ & $\begin{array}{l}63.1 \\
(0.2)\end{array}$ & - \\
\hline Stock owner $(\%)$ & $\begin{array}{l}65.5 \\
(1.9)\end{array}$ & $\begin{array}{l}71.7 \\
(2.3)\end{array}$ & $\begin{array}{l}69.3 \\
(2.5)\end{array}$ & $\begin{array}{l}73.2 \\
(2.2)\end{array}$ & $\begin{array}{l}63.1 \\
(1.0)\end{array}$ \\
\hline Stock in $1992(\$)$ & $\begin{array}{l}53,733 \\
(6,188)\end{array}$ & $\begin{array}{l}56,537 \\
(6,764)\end{array}$ & $\begin{array}{c}64,516 \\
(13,495)\end{array}$ & $\begin{array}{l}50,947 \\
(5,938)\end{array}$ & $\begin{array}{l}42,116 \\
(3,389)\end{array}$ \\
\hline $\begin{array}{l}\text { Stock as percent of financial } \\
\text { assets in } 1992\end{array}$ & $\begin{array}{l}27.5 \\
(1.2)\end{array}$ & $\begin{array}{l}29.2 \\
(1.4)\end{array}$ & $\begin{array}{l}31.7 \\
(1.6)\end{array}$ & $\begin{array}{l}28.8 \\
(1.4)\end{array}$ & $\begin{array}{l}26.3 \\
(0.6)\end{array}$ \\
\hline Net Worth in 1992 (\$) & $\begin{array}{l}249,005 \\
(16,708)\end{array}$ & $\begin{array}{l}247,670 \\
(16,677)\end{array}$ & $\begin{array}{l}218,617 \\
(18,094)\end{array}$ & $\begin{array}{l}281,411 \\
(21,097)\end{array}$ & $\begin{array}{l}231,468 \\
(10,706)\end{array}$ \\
\hline Has DB pension $(\%)$ & $\begin{array}{l}42.3 \\
(2.0)\end{array}$ & $\begin{array}{l}59.2 \\
(2.5)\end{array}$ & $\begin{array}{l}42.8 \\
(2.7)\end{array}$ & $\begin{array}{l}51.5 \\
(2.5)\end{array}$ & $\begin{array}{l}36.4 \\
(1.0)\end{array}$ \\
\hline $\begin{array}{l}\text { Has employer-provided } \\
\text { health insurance through own } \\
\text { employer }\end{array}$ & $\begin{array}{l}56.8 \\
(2.0)\end{array}$ & $\begin{array}{l}67.1 \\
(2.4)\end{array}$ & $\begin{array}{l}66.6 \\
(2.6)\end{array}$ & $\begin{array}{l}68.2 \\
(2.3)\end{array}$ & $\begin{array}{l}58.8 \\
(1.0)\end{array}$ \\
\hline $\begin{array}{l}\text { Has employer-provided } \\
\text { health insurance through } \\
\text { spouse }\end{array}$ & $\begin{array}{l}21.6 \\
(1.7)\end{array}$ & $\begin{array}{l}16.4 \\
(1.9)\end{array}$ & $\begin{array}{l}20.2 \\
(2.2)\end{array}$ & $\begin{array}{l}14.7 \\
(1.8)\end{array}$ & $\begin{array}{l}20.9 \\
(0.8)\end{array}$ \\
\hline $\begin{array}{l}\text { Has retiree health insurance } \\
(\%)\end{array}$ & $\begin{array}{l}59.8 \\
(2.0)\end{array}$ & $\begin{array}{l}67.9 \\
(2.4)\end{array}$ & $\begin{array}{l}61.1 \\
(2.7)\end{array}$ & $\begin{array}{l}58.2 \\
(2.5)\end{array}$ & $\begin{array}{l}50.9 \\
(1.0)\end{array}$ \\
\hline $\begin{array}{l}\text { Offered early retirement } \\
\text { incentive }(\%)\end{array}$ & $\begin{array}{l}19.3 \\
(1.6)\end{array}$ & $\begin{array}{l}17.4 \\
(1.9)\end{array}$ & $\begin{array}{l}13.5 \\
(1.9)\end{array}$ & $\begin{array}{l}15.6 \\
(1.8)\end{array}$ & $\begin{array}{c}9.6 \\
(0.6)\end{array}$ \\
\hline
\end{tabular}




\section{Table 1(continued): Means of Selected Variables by Timing of Retirement Relative to Expectations}

\begin{tabular}{|c|c|c|c|c|c|}
\hline & \multicolumn{2}{|c|}{ Retired between 1993 and 1996} & \multicolumn{2}{|c|}{ Retired between 1997 and 2000} & \multirow{2}{*}{$\begin{array}{c}\text { Not Retired } \\
-\end{array}$} \\
\hline & Early & On time or late & Early & On time or late & \\
\hline \multicolumn{6}{|l|}{ Health } \\
\hline $\begin{array}{l}\text { Fair or poor health in } 1992 \\
(\%)\end{array}$ & $\begin{array}{l}17.0 \\
(1.5)\end{array}$ & $\begin{array}{l}12.6 \\
(1.7)\end{array}$ & $\begin{array}{l}11.3 \\
(1.7)\end{array}$ & $\begin{array}{c}5.2 \\
(1.1)\end{array}$ & $\begin{array}{c}7.6 \\
(0.5)\end{array}$ \\
\hline $\begin{array}{l}\text { Health shock between } 1992 \\
\text { and } 1994(\%)\end{array}$ & $\begin{array}{c}8.0 \\
(1.1)\end{array}$ & $\begin{array}{c}6.2 \\
(1.2)\end{array}$ & $\begin{array}{l}3.5 \\
(1.0)\end{array}$ & $\begin{array}{c}4.0 \\
(1.0)\end{array}$ & $\begin{array}{c}2.8 \\
(0.3)\end{array}$ \\
\hline Ever had health shock (\%) & $\begin{array}{l}28.3 \\
(1.8)\end{array}$ & $\begin{array}{l}29.6 \\
(2.3)\end{array}$ & $\begin{array}{l}29.1 \\
(2.5)\end{array}$ & $\begin{array}{l}26.2 \\
(2.2)\end{array}$ & $\begin{array}{l}18.8 \\
(0.8)\end{array}$ \\
\hline $\mathrm{N}$ & 610 & 398 & 338 & 400 & 2383 \\
\hline
\end{tabular}




\section{Table 2: Determinants of Retirement Behavior}

\begin{tabular}{|c|c|c|}
\hline & \multicolumn{2}{|c|}{ Dependent Variable } \\
\hline & $\begin{array}{r}\text { Deviations from } \\
\text { Retirement Expectations }\end{array}$ & Retirement Year \\
\hline \multicolumn{3}{|l|}{ Economic Status } \\
\hline Stockowner & $\begin{array}{l}-0.243 \\
(-3.31)\end{array}$ & $\begin{array}{l}-0.476 \\
(-3.19)\end{array}$ \\
\hline Unanticipated equity gains* & $\begin{array}{l}-0.413 \\
(-1.89)\end{array}$ & $\begin{array}{l}-0.809 \\
(-1.84)\end{array}$ \\
\hline Net worth* & $\begin{array}{l}-0.275 \\
(-2.41)\end{array}$ & $\begin{array}{l}-0.556 \\
(-2.43)\end{array}$ \\
\hline Ratio of net worth to income & $\begin{array}{l}-0.000 \\
(-0.66)\end{array}$ & $\begin{array}{l}-0.001 \\
(-0.59)\end{array}$ \\
\hline Has DB pension & $\begin{array}{l}-0.434 \\
(-5.55)\end{array}$ & $\begin{array}{l}-0.882 \\
(-5.58)\end{array}$ \\
\hline Self-employed & $\begin{array}{l}0.641 \\
(6.83)\end{array}$ & $\begin{array}{r}1.38 \\
(6.79)\end{array}$ \\
\hline \multicolumn{3}{|l|}{${\text { Health status }(1992)^{* *}}^{* *}$} \\
\hline Excellent & $\begin{array}{r}0.679 \\
(2.98)\end{array}$ & $\begin{array}{r}1.40 \\
(2.86)\end{array}$ \\
\hline Very Good & $\begin{array}{r}0.758 \\
(3.20)\end{array}$ & $\begin{array}{r}1.52 \\
(3.10)\end{array}$ \\
\hline Good & $\begin{array}{r}0.791 \\
(3.44)\end{array}$ & $\begin{array}{r}1.61 \\
(3.31)\end{array}$ \\
\hline Fair & $\begin{array}{l}0.530 \\
(2.30)\end{array}$ & $\begin{array}{r}1.10 \\
(2.22)\end{array}$ \\
\hline $\begin{array}{l}\text { Employer-provided health } \\
\text { insurance (covers self only) }\end{array}$ & $\begin{array}{r}0.538 \\
(4.69)\end{array}$ & $\begin{array}{r}1.08 \\
(4.46)\end{array}$ \\
\hline Retiree health insurance & $\begin{array}{l}-0.482 \\
(-5.40)\end{array}$ & $\begin{array}{l}-0.965 \\
(-5.27)\end{array}$ \\
\hline Health shock in first wave & $\begin{array}{l}-0.288 \\
(-2.27)\end{array}$ & $\begin{array}{l}-0.610 \\
(-2.10)\end{array}$ \\
\hline Pseudo R-squared & 0.06 & 0.17 \\
\hline Number of Individuals & & 3675 \\
\hline
\end{tabular}

Marginal effects are presented with t-statistics in parentheses. Omitted from the table are dummy variables for age of respondent and years of retirement as well as a number of other economic and health variables. A complete presentation of the results is in the appendix.

* Value in millions.

** Poor health omitted. 
Table 3: Determinants of Retirement Behavior by Gender

\begin{tabular}{|c|c|c|}
\hline & Female & Male \\
\hline \multicolumn{3}{|l|}{ Economic Status } \\
\hline Stockowner & $\begin{array}{l}-0.665 \\
(-3.01)\end{array}$ & $\begin{array}{l}-0.283 \\
(-1.33)\end{array}$ \\
\hline Unanticipated equity gains* & $\begin{array}{l}-0.312 \\
(-0.53)\end{array}$ & $\begin{array}{r}-1.57 \\
(-2.33)\end{array}$ \\
\hline Net worth* & $\begin{array}{r}-1.21 \\
(-3.94)\end{array}$ & $\begin{array}{l}0.527 \\
(1.30)\end{array}$ \\
\hline Ratio of net worth to income & $\begin{array}{r}0.000 \\
(0.39)\end{array}$ & $\begin{array}{l}-0.019 \\
(-2.64)\end{array}$ \\
\hline Has $\mathrm{db}$ pension & $\begin{array}{l}-0.584 \\
(-2.69)\end{array}$ & $\begin{array}{r}-1.17 \\
(-4.92)\end{array}$ \\
\hline Self-employed & $\begin{array}{r}1.42 \\
(5.78)\end{array}$ & $\begin{array}{r}1.43 \\
(3.98)\end{array}$ \\
\hline \multicolumn{3}{|l|}{ Health status $(1992)^{* *}$} \\
\hline Excellent & $\begin{array}{r}0.946 \\
(1.39)\end{array}$ & $\begin{array}{r}1.98 \\
(2.82)\end{array}$ \\
\hline Very good & $\begin{array}{c}0.944 \\
(1.40)\end{array}$ & $\begin{array}{r}2.18 \\
(3.08)\end{array}$ \\
\hline Good & $\begin{array}{r}1.19 \\
(1.80)\end{array}$ & $\begin{array}{r}2.26 \\
(3.26)\end{array}$ \\
\hline Fair & $\begin{array}{r}1.20 \\
(1.79)\end{array}$ & $\begin{array}{r}1.23 \\
(1.70)\end{array}$ \\
\hline $\begin{array}{l}\text { Employer-provided health } \\
\text { insurance }\end{array}$ & $\begin{array}{l}0.659 \\
(2.17)\end{array}$ & $\begin{array}{r}1.51 \\
(3.84)\end{array}$ \\
\hline Retiree health insurance & $\begin{array}{l}-0.578 \\
(-2.33)\end{array}$ & $\begin{array}{r}-1.18 \\
(-4.31)\end{array}$ \\
\hline Health shock in first wave & $\begin{array}{r}0.428 \\
(0.88)\end{array}$ & $\begin{array}{l}-0.618 \\
(-3.16)\end{array}$ \\
\hline Pseudo R-squared & 0.20 & 0.16 \\
\hline Number of Individuals & 1934 & 1741 \\
\hline
\end{tabular}

Marginal effects are presented with t-statistics in parentheses. Omitted from the table are dummy variables for age of respondent and years of retirement as well as a number of other economic and health variables. A complete presentation of the results is in the appendix.

* Value in millions. $\quad * *$ Poor health omitted. 
Table 4: Determinants of Retirement Behavior by Employment Status

\begin{tabular}{|c|c|c|}
\hline & Wage and Salary & Self-Employed \\
\hline \multicolumn{3}{|l|}{ Economic Status } \\
\hline Stockowner & $\begin{array}{l}-0.447 \\
(-2.77)\end{array}$ & $\begin{array}{l}-0.886 \\
(-2.08)\end{array}$ \\
\hline Unanticipated equity gains* & $\begin{array}{l}-0.392 \\
(-0.70)\end{array}$ & $\begin{array}{r}-1.87 \\
(-2.91)\end{array}$ \\
\hline Net worth* & $\begin{array}{r}-1.72 \\
(-4.67)\end{array}$ & $\begin{array}{l}0.798 \\
(2.40)\end{array}$ \\
\hline Ratio of net worth to income & $\begin{array}{r}0.002 \\
(1.26)\end{array}$ & $\begin{array}{l}-0.012 \\
(-2.24)\end{array}$ \\
\hline Has $\mathrm{db}$ pension & $\begin{array}{l}-0.868 \\
(-5.12)\end{array}$ & $\begin{array}{r}-3.27 \\
(-5.15)\end{array}$ \\
\hline \multicolumn{3}{|l|}{${\text { Health status }(1992)^{* *}}^{* *}$} \\
\hline Excellent & $\begin{array}{r}1.42 \\
(2.71)\end{array}$ & $\begin{array}{r}2.35 \\
(1.90)\end{array}$ \\
\hline Very good & $\begin{array}{r}1.44 \\
(2.76)\end{array}$ & $\begin{array}{r}3.08 \\
(2.25)\end{array}$ \\
\hline Good & $\begin{array}{r}1.61 \\
(3.12)\end{array}$ & $\begin{array}{r}2.85 \\
(2.28)\end{array}$ \\
\hline Fair & $\begin{array}{r}1.06 \\
(2.01)\end{array}$ & $\begin{array}{r}2.15 \\
(1.69)\end{array}$ \\
\hline $\begin{array}{l}\text { Employer-provided health } \\
\text { insurance }\end{array}$ & $\begin{array}{r}0.886 \\
(3.28)\end{array}$ & $\begin{array}{r}0.890 \\
(1.49)\end{array}$ \\
\hline Retiree health insurance & $\begin{array}{l}-0.817 \\
(-4.01)\end{array}$ & $\begin{array}{l}-0.438 \\
(-0.99)\end{array}$ \\
\hline Health shock in first wave & $\begin{array}{l}-0.719 \\
(-2.23)\end{array}$ & $\begin{array}{l}-0.975 \\
(-1.37)\end{array}$ \\
\hline Pseudo R-squared & 0.16 & 0.27 \\
\hline Number of Individuals & 3054 & 621 \\
\hline
\end{tabular}

Marginal effects are presented with t-statistics in parentheses. Omitted from the table are dummy variables for age of respondent and years of retirement as well as a number of other economic and health variables. A complete presentation of the results is in the appendix.

* Value in millions.

** Poor health omitted. 
Table 5: Means of Selected Variables by Measure of Risk Aversion

\begin{tabular}{|c|c|c|c|c|}
\hline & \multicolumn{4}{|c|}{ Risk Aversion Category } \\
\hline & $\begin{array}{l}\text { Least risk } \\
\text { averse }\end{array}$ & & & $\begin{array}{l}\text { Most risk } \\
\text { averse }\end{array}$ \\
\hline & 1 & 2 & 3 & 4 \\
\hline 1. Percent stock owner & $\begin{array}{l}64.2 \\
(2.2)\end{array}$ & $\begin{array}{l}63.7 \\
(2.3)\end{array}$ & $\begin{array}{l}69.1 \\
(2.1)\end{array}$ & $\begin{array}{l}66.5 \\
(0.9)\end{array}$ \\
\hline 2. Stock level in $1992(\$)$ & $\begin{array}{c}66,049 \\
(11,400)\end{array}$ & $\begin{array}{l}34,780 \\
(3,762)\end{array}$ & $\begin{array}{l}44,791 \\
(4,878)\end{array}$ & $\begin{array}{l}47,543 \\
(3,160)\end{array}$ \\
\hline $\begin{array}{l}\text { 3. Percent of financial } \\
\text { assets in stock }\end{array}$ & $\begin{array}{l}27.7 \\
(1.4)\end{array}$ & $\begin{array}{l}27.6 \\
(1.4)\end{array}$ & $\begin{array}{l}28.8 \\
(1.3)\end{array}$ & $\begin{array}{l}27.2 \\
(0.6)\end{array}$ \\
\hline $\begin{array}{l}\text { 4. Percent retired earlier } \\
\text { than expected }\end{array}$ & $\begin{array}{l}20.9 \\
(1.9)\end{array}$ & $\begin{array}{l}21.8 \\
(1.9)\end{array}$ & $\begin{array}{l}23.5 \\
(1.9)\end{array}$ & $\begin{array}{l}25.0 \\
(0.8)\end{array}$ \\
\hline $\mathrm{N}$ & 463 & 448 & 503 & 2,733 \\
\hline
\end{tabular}


Figure 1

Retirement Patterns for HRS Sample
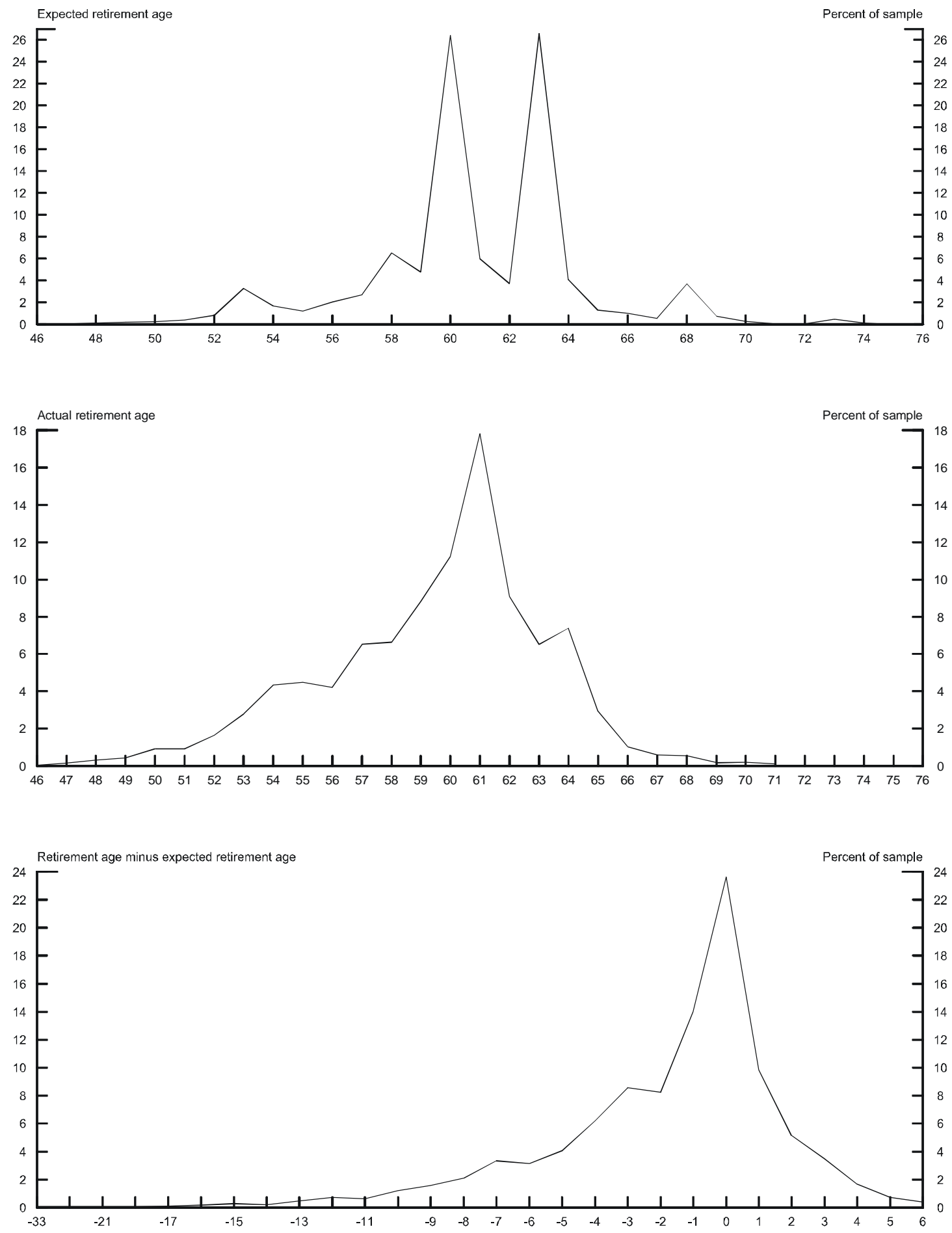


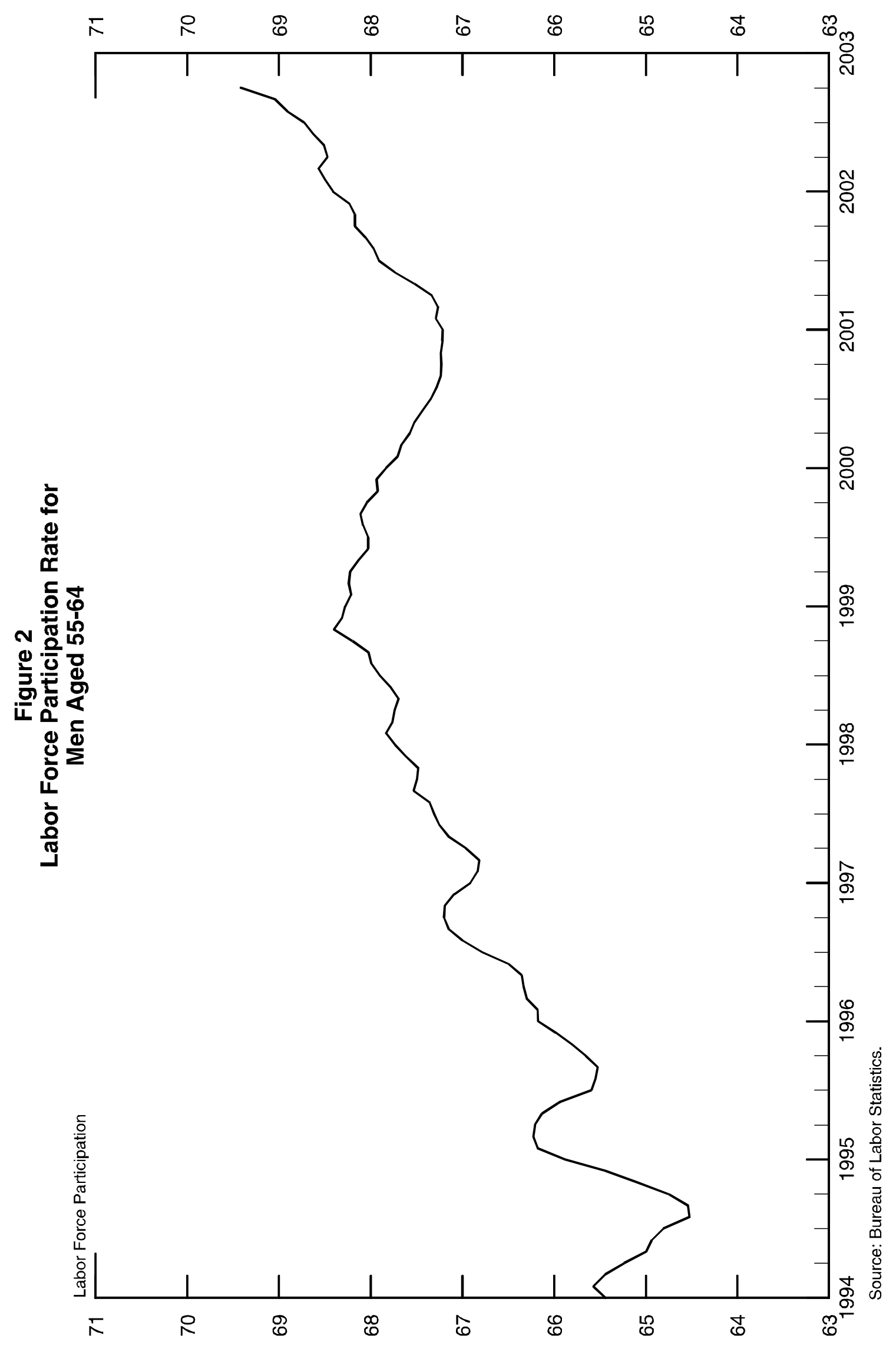




\section{Data Appendix}

The table below describes how all of the variables used in this analysis were constructed using data from the Health and Retirement Study (HRS). The definition of retirement used in this paper, shown in the first row, warrants further discussion. A respondent is classified as retired if they report that they consider themselves to be "completely retired," as opposed to "partly retired" or "not retired at all." We use this self-defined retirement measure because it aligns most closely with the retirement expectations question, which asks "When do you think you will retire completely?"

There are other measures available in the HRS that could be used to determine retirement status, such as hours worked for pay during the year. In fact, Gustman and Steinmeier (2000) compared self-reported retirement status with measures of retirement based on hours of work. The hours-based measure indicates fewer respondents are still in the labor force in the initial wave, perhaps because some respondents were unemployed or taking time off between jobs. However, by wave 4, the self-reported retirement measure implied roughly the same fraction of retirees in the sample as the hours-based measure. The self-reported measure thus indicates a greater flow into retirement over time. 


\section{Description of Variables*}

Variable Name

Retirement year

Year (i); i=1993 to 2008+;

Stock owner

Unanticipated equity gain

Net worth

Ratio of net worth to income

Has DB plan

Male

Self-employed

\section{Definition}

Year that respondent reported they "completely retired"

Dummy variable equal to 1 if the respondent expected to retire in year i, 0 otherwise

Dummy variable equal to 1 if respondent (or respondent's spouse) held stock directly or indirectly through mutual funds, trusts, defined contribution plans or IRAs.

Represents gain on equities in held in 1992 and assumed to be held in excess of what might be expected based on historical experience (as measured by the Wilshire 5000 index), calculated as equal the value of stock in 1992 held directly or indirectly through mutual funds, trusts, defined contribution plans or IRAs (db plan, ira, and general) multiplied by 1.52

Total wealth equal to the value of financial and tangible assets less the amount of debt outstanding. Financial assets include: business equity, IRA and Keogh accounts, stocks (including stock mutual funds and those in investment trusts), bonds and bond funds, checking and savings accounts, money market accounts, and other financial assets. Tangible assets include: vehicles and real estate (both primary residences and other real estate). Debt outstanding includes the value of mortgages and other debt.

Net worth divided by household (respondent and spouse) income (includes wage and salary, bonuses, outliers, pay, commissions, tips, $2^{\text {nd }}$ job military reserve earnings, professional practice or trade income)

Dummy variable equal to 1 if the respondent has a defined benefit pension plan, 0 otherwise

Dummy variable equal to 1 if the respondent is male, 0 otherwise

Dummy variable equal to 1 if the respondent is self-employed, 0 otherwise 


\section{Description of Variables* (continued)}

\section{Variable Name}

\section{Definition}

\section{Education}

Education level (e); e=High Dummy variable equal to 1 if the respondent's highest school graduate, some college, educational level is e, 0 otherwise

college graduate, or some

graduate school

Health

Self reported health status (h); Dummy variable equal to 1 if the respondent reported health $\mathrm{h}=$ Excellent, very good, good, status h, 0 if otherwise

fair

\section{Employer-provided health}

insurance

$\mathrm{R}$ covers self and spouse

Dummy variable equal to 1 if the respondent has employerprovided health insurance that covers both the respondent and spouse, 0 otherwise

$\mathrm{R}$ covers self only
$\mathrm{R}$ covered by spouse

$\mathrm{R}$ has coverage through both self and spouse

\section{R covers self only}

Dummy variable equal to 1 if the respondent has employerprovided health insurance that covers only the respondent, 0 otherwise

Dummy variable equal to 1 if the respondent is covered by the spouse's employer-provided health insurance, 0 otherwise

Dummy variable equal to 1 if the respondent is covered by the both the respondent's and spouse's employer-provided health insurance, 0 otherwise

$\mathrm{R}$ has retiree health insurance Dummy variable equal to 1 if the respondent is covered by through self or spouse

\section{Marital Status}

Self reported marital status $(\mathrm{m}) ; \mathrm{m}=$ Divorced or separated, widowed, or married

Offered early out

Early out between waves (ij); Dummy variable equal to 1 if the respondent was offered an $\mathrm{ij}=1992$ and 1994, 1994 and early retirement incentive between waves $\mathrm{ij}, 0$ otherwise 1996, and 1996 and 1998

Change in marital status between 1992 and 2000 Ever (ms); ms=divorced, widowed, or married
Dummy variable equal to 1 if the respondent's marital status is $\mathrm{m}, 0$ otherwise otherwise

Dummy variable equal to 1 if the respondent ever changed marital status to ms between 1992 and 2000, 0 otherwise 


\section{Description of Variables* (continued)}

Variable Name

Health shock

Health shock between waves

(ij); ij=1992, 1994; 1994,

1996; 1996, 1998; 1998, 2000 stroke between the specified waves (ij), 0 otherwise

Health ever deteriorated from Dummy variable equal to 1 if respondent's self-reported one wave to next

health status deteriorated from any wave to the next wave, 0 otherwise

Spouse's health ever Dummy variable equal to 1 if spouse's self reported health deteriorated from one wave to status deteriorated from any wave to the next wave, 0 next otherwise

Spouse ever had health shock Dummy variable equal to 1 if the spouse was diagnosed with cancer, heart disease, or lung disease, or experienced a stroke between any wave and the next wave, 0 otherwise

Spouse retired between 1992 Dummy variable equal to 1 if spouse self-reported retirement and 2000 status changed from working to retired in any wave, 0 otherwise

Risk aversion category (1-4) $1=$ Yes, Yes

$2=$ Yes, No

$3=$ No, Yes

$4=\mathrm{No}$, No
Respondents are ranked according to their answers to the following three questions:

Suppose that you are the only income earner in the family, and you have a good job guaranteed to give you your current (family) income every year for life. You are given the opportunity to take a new and equally good job, with a 50-50 chance it will double your (family) income and a 50-50 chance that it will cut your (family) income by a third. Would you take the new job (yes, no)?

If yes, then: Suppose the chances were 50-50 that it would double your (family) income, and 50-50 that it would cut it in half. Would you still take the new job (yes, no)?

If no, then: Suppose the chances were 50-50 that it would double your (family) income and 50-50 that it would cut it by 20 percent. Would you then take the new job (yes, no)?

Number of observations

* All variables measured at first wave (1992) unless otherwise specified. 
Appendix

Complete Regression Results

Dependent Variable: Deviations from retirement expectations

\begin{tabular}{|c|c|c|}
\hline Variable Name & Marginal Effect & T-Statistic \\
\hline \multicolumn{3}{|l|}{ Expected Retirement Year } \\
\hline 1993 & -5.811 & -4.66 \\
\hline 1994 & -10.703 & -4.71 \\
\hline 1995 & -12.041 & -4.90 \\
\hline 1996 & -12.418 & -4.94 \\
\hline 1997 & -12.754 & -4.99 \\
\hline 1998 & -12.685 & -4.89 \\
\hline 1999 & -11.698 & -4.54 \\
\hline 2000 & -11.871 & -4.53 \\
\hline 2001 & -9.412 & -3.69 \\
\hline 2002 & -8.944 & -3.52 \\
\hline 2003 & -7.841 & -3.04 \\
\hline 2004 & -6.482 & -2.53 \\
\hline 2005 & -4.675 & -1.86 \\
\hline 2006 & -5.311 & -2.03 \\
\hline 2007 & -1.834 & -0.75 \\
\hline 2008 & -1.235 & -0.47 \\
\hline Stock owner & -0.243 & -3.31 \\
\hline Unanticipated equity gain (millions) & -0.413 & -1.89 \\
\hline Net worth (millions) & -0.275 & -2.41 \\
\hline Ratio of net worth to income & -0.000 & -0.66 \\
\hline Has DB plan & -0.434 & -5.55 \\
\hline Male & 0.183 & 2.38 \\
\hline Self-employed & 0.641 & 6.83 \\
\hline \multicolumn{3}{|l|}{ Education } \\
\hline High school graduate & 0.094 & 1.08 \\
\hline Some college & 0.429 & 4.04 \\
\hline College graduate & 0.278 & 2.17 \\
\hline Some graduate school & 0.485 & 4.27 \\
\hline \multicolumn{3}{|l|}{ Health } \\
\hline Excellent & 0.679 & 2.98 \\
\hline Very good & 0.758 & 3.20 \\
\hline Good & 0.791 & 3.44 \\
\hline Fair & 0.530 & 2.30 \\
\hline
\end{tabular}


Dependent Variable: Deviations from retirement expectations (continued)

Variable Name

Marginal Effect T-Statistic

Employer-provided health insurance

$\mathrm{R}$ covers self and spouse

$0.564 \quad 4.88$

$\mathrm{R}$ covers self only

$0.538 \quad 4.69$

$\mathrm{R}$ covered by spouse

$0.458 \quad 3.67$

$\mathrm{R}$ has coverage through both self and spouse

$0.652 \quad 4.11$

$\mathrm{R}$ has retiree health insurance through self or spouse

$-0.482 \quad-5.40$

Marital Status

Divorced or separated

0.500

2.14

Widowed

0.697

3.01

Married

1.179

4.03

Offered early out

between 1992 and 1994

$-0.288$

$-2.55$

between 1994 and 1996

0.083

0.47

between 1996 and 1998

0.089

0.44

Change in marital status between 1992 and 2000

ever divorced

0.498

2.45

ever widowed

0.222

1.68

ever married

$-0.500 \quad-1.51$

Health shock

between 1992 and 1994

$-0.342$

$-2.27$

between 1994 and 1996

$-0.278$

$-1.62$

between 1996 and 1998

$-0.032$

$-0.27$

between 1998 and 2000

$-0.281 \quad-2.82$

Health ever deteriorated from one wave to next

$-0.208 \quad-2.84$

Spouse's health ever deteriorated from one wave to next

$-0.012 \quad-0.16$

Spouse ever had health shock

$-0.064 \quad-0.76$

Spouse retired between 1992 and 2000

$-0.384$

$-5.26$ 


\begin{tabular}{lrr}
\hline Variable Name & Marginal Effect & T-Statistic \\
\hline & & \\
Expected Retirement Year & & \\
1993 & -20.110 & -10.70 \\
1994 & -32.822 & -10.43 \\
1995 & -33.999 & -10.30 \\
1996 & -33.469 & -10.02 \\
1997 & -32.713 & -9.73 \\
1998 & -31.543 & -9.30 \\
1999 & -29.268 & -8.60 \\
2000 & -28.246 & -8.22 \\
2001 & -24.215 & -7.03 \\
2002 & -22.523 & -6.52 \\
2003 & -20.082 & -5.62 \\
2004 & -17.363 & -4.75 \\
2005 & -14.058 & -3.69 \\
2006 & -13.668 & -3.55 \\
2007 & -7.950 & -1.81 \\
2008 & -5.771 & -1.16
\end{tabular}

$\underline{\text { Economic Status }}$

Stock owner

$-0.476 \quad-3.19$

Unanticipated equity gain (millions)

$-0.809 \quad-1.84$

Net worth (millions)

$-0.556 \quad-2.43$

Ratio of net worth to income

$-0.001 \quad-0.59$

Has DB plan

$\begin{array}{ll}-0.882 & -5.58\end{array}$

Male

$0.366 \quad 2.37$

Self-employed

1.384

6.79

Education

High school graduate

$0.176 \quad 1.00$

Some college

$0.867 \quad 3.88$

College graduate

$0.572 \quad 2.14$

Some graduate school

$1.016 \quad 4.20$

Health

Excellent

$1.400 \quad 2.86$

Very good

$1.522 \quad 3.10$

Good

$1.606 \quad 3.31$

Fair

$1.100 \quad 2.22$




\section{Dependent Variable: Retirement year (continued)}

Variable Name

Marginal Effect T-Statistic

Employer-provided health insurance

$R$ covers self and spouse

$1.103 \quad 4.65$

$R$ covers self only

$1.077 \quad 4.46$

$\mathrm{R}$ covered by spouse

$0.930 \quad 3.54$

$\mathrm{R}$ has coverage through both self and spouse

$1.393 \quad 3.92$

$\mathrm{R}$ has retiree health insurance through self or spouse

$-0.965 \quad-5.27$

$\underline{\text { Marital Status }}$

Divorced or separated

$1.043 \quad 2.06$

Widowed

$1.507 \quad 2.88$

Married

$2.089 \quad 3.94$

Offered early out

between 1992 and 1994

$-0.512 \quad-2.33$

between 1994 and 1996

$0.092 \quad 0.25$

between 1996 and 1998

$0.091 \quad 0.22$

Change in marital status between 1992 and 2000

ever divorced

$1.073 \quad 2.42$

ever widowed

$0.415 \quad 1.52$

ever married

$-1.023 \quad-1.63$

Health shock

between 1992 and 1994

$-0.610 \quad-2.10$

between 1994 and 1996

$-0.535 \quad-1.60$

between 1996 and 1998

$-0.080 \quad-0.34$

between 1998 and 2000

$-0.542 \quad-2.77$

Health ever deteriorated from one wave to next

$\begin{array}{ll}-0.404 & -2.76\end{array}$

Spouse's health ever deteriorated from one wave to next

$-0.013 \quad-0.09$

Spouse ever had health shock

$-0.150 \quad-0.89$

Spouse retired between 1992 and 2000

$-0.772$

$-5.34$ 


\section{Results by Gender}

Dependent Variable: Retirement year

\begin{tabular}{|c|c|c|c|c|}
\hline \multirow[b]{2}{*}{ Variable Name } & \multicolumn{2}{|c|}{ Female } & \multicolumn{2}{|c|}{ Male } \\
\hline & $\begin{array}{c}\text { Marginal } \\
\text { Effect }\end{array}$ & T-Statistic & $\begin{array}{c}\text { Marginal } \\
\text { Effect }\end{array}$ & T-Statistic \\
\hline \multicolumn{5}{|l|}{ Expected Retirement Year } \\
\hline 1993 & -19.099 & -8.76 & -19.479 & -6.31 \\
\hline 1994 & -27.008 & -8.29 & -35.366 & -6.27 \\
\hline 1995 & -27.695 & -8.08 & -36.456 & -6.21 \\
\hline 1996 & -27.528 & -7.97 & -35.815 & -6.01 \\
\hline 1997 & -26.904 & -7.74 & -35.274 & -5.89 \\
\hline 1998 & -25.228 & -7.20 & -35.043 & -5.80 \\
\hline 1999 & -24.390 & -6.93 & -31.073 & -5.14 \\
\hline 2000 & -23.736 & -6.66 & -29.591 & -4.86 \\
\hline 2001 & -19.835 & -5.48 & -26.373 & -4.34 \\
\hline 2002 & -18.691 & -5.23 & -23.513 & -3.83 \\
\hline 2003 & -14.968 & -3.94 & -23.408 & -3.76 \\
\hline 2004 & -15.380 & -4.01 & -17.636 & -2.75 \\
\hline 2005 & -11.535 & -2.84 & -14.620 & -2.22 \\
\hline 2006 & -13.086 & -3.29 & -10.302 & -1.49 \\
\hline 2007 & -0.6942 & -1.52 & -8.098 & -1.04 \\
\hline 2008 & -3.011 & -0.59 & -10.060 & -1.11 \\
\hline Stock owner & -0.665 & -3.01 & -0.283 & -1.33 \\
\hline Unanticipated equity gain (millions) & -0.312 & -0.53 & -1.570 & -2.33 \\
\hline Net worth (millions) & -1.210 & -3.94 & 0.527 & 1.30 \\
\hline Ratio of net worth to income & 0.000 & 0.39 & -0.019 & -2.64 \\
\hline Has DB plan & -0.584 & -2.69 & -1.168 & -4.92 \\
\hline Self-employed & 1.424 & 5.78 & 1.434 & 3.98 \\
\hline \multicolumn{5}{|l|}{ Education } \\
\hline High school graduate & -0.299 & -1.15 & 0.541 & 2.15 \\
\hline Some college & 0.391 & 1.23 & 1.306 & 3.92 \\
\hline College graduate & -0.127 & -0.29 & 1.218 & 3.49 \\
\hline Some graduate school & 0.951 & 2.69 & 1.185 & 3.41 \\
\hline \multicolumn{5}{|l|}{ Health } \\
\hline Excellent & 0.946 & 1.39 & 1.976 & 2.82 \\
\hline Very good & 0.944 & 1.40 & 2.181 & 3.08 \\
\hline Good & 1.195 & 1.80 & 2.262 & 3.26 \\
\hline Fair & 1.198 & 1.79 & 1.230 & 1.70 \\
\hline
\end{tabular}




\section{Results by Gender}

Dependent Variable: Retirement year (continued)

\begin{tabular}{|c|c|c|c|c|}
\hline \multirow[b]{2}{*}{ Variable Name } & \multicolumn{2}{|c|}{ Female } & \multicolumn{2}{|c|}{ Male } \\
\hline & $\begin{array}{c}\text { Marginal } \\
\text { Effect }\end{array}$ & T-Statistic & $\begin{array}{c}\text { Marginal } \\
\text { Effect }\end{array}$ & T-Statistic \\
\hline \multicolumn{5}{|l|}{ Employer-provided health insurance } \\
\hline $\mathrm{R}$ covers self and spouse & 0.952 & 2.75 & 1.230 & 3.46 \\
\hline $\mathrm{R}$ covers self only & 0.659 & 2.17 & 1.512 & 3.84 \\
\hline $\mathrm{R}$ covered by spouse & 1.019 & 3.12 & 0.330 & 0.74 \\
\hline $\mathrm{R}$ has coverage through both self and spouse & 0.442 & 0.89 & 2.163 & 4.08 \\
\hline $\mathrm{R}$ has retiree health insurance through self or spouse & -0.577 & -2.33 & -1.180 & -4.31 \\
\hline \multicolumn{5}{|l|}{$\underline{\text { Marital Status }}$} \\
\hline Divorced or separated & 1.031 & 1.71 & 1.429 & 1.65 \\
\hline Widowed & 1.709 & 2.91 & 0.673 & 0.56 \\
\hline Married & 2.039 & 3.12 & 2.793 & 3.23 \\
\hline \multicolumn{5}{|l|}{$\underline{\text { Offered early out }}$} \\
\hline between 1992 and 1994 & -0.953 & -2.88 & -0.618 & -1.98 \\
\hline between 1994 and 1996 & 0.135 & 0.28 & 0.399 & 0.73 \\
\hline between 1996 and 1998 & -0.129 & -0.22 & 0.514 & 0.85 \\
\hline \multicolumn{5}{|l|}{ Change in marital status between 1992 and 2000} \\
\hline ever divorced & 1.493 & 2.28 & 0.855 & 1.38 \\
\hline ever widowed & 0.172 & 0.58 & 1.069 & 1.89 \\
\hline ever married & 0.950 & 1.07 & -2.338 & -2.50 \\
\hline \multicolumn{5}{|l|}{ Health shock } \\
\hline between 1992 and 1994 & 0.428 & 0.88 & -1.231 & -3.16 \\
\hline between 1994 and 1996 & -0.575 & -1.28 & -0.060 & -0.12 \\
\hline between 1996 and 1998 & 0.332 & 0.96 & -0.257 & -0.74 \\
\hline between 1998 and 2000 & -0.628 & -2.32 & -0.478 & -1.63 \\
\hline Health ever deteriorated from one wave to next & -0.532 & -2.71 & -0.343 & -1.58 \\
\hline Spouse's health ever deteriorated from wave to wave & -0.389 & -1.96 & 0.218 & 1.03 \\
\hline Spouse ever had health shock & -0.178 & -0.78 & -0.107 & -0.42 \\
\hline Spouse retired between 1992 and 2000 & -0.558 & -2.77 & -0.892 & -4.21 \\
\hline
\end{tabular}


Results by Employment Status

Dependent variable: retirement year

\begin{tabular}{|c|c|c|c|c|}
\hline \multirow[b]{2}{*}{ Variable Name } & \multicolumn{2}{|c|}{ Wage and Salary Workers } & \multicolumn{2}{|c|}{ Self-Employed } \\
\hline & $\begin{array}{c}\text { Marginal } \\
\text { Effect }\end{array}$ & T-Statistic & $\begin{array}{l}\text { Marginal } \\
\text { Effect }\end{array}$ & T-Statistic \\
\hline \multicolumn{5}{|l|}{ Expected Retirement Year } \\
\hline 1993 & -19.752 & -9.28 & -16.138 & -5.07 \\
\hline 1994 & -32.259 & -9.03 & -24.313 & -4.82 \\
\hline 1995 & -33.173 & -8.89 & -27.744 & -5.18 \\
\hline 1996 & -32.682 & -8.66 & -25.969 & -4.78 \\
\hline 1997 & -31.995 & -8.43 & -26.423 & -4.84 \\
\hline 1998 & -30.933 & -8.10 & -23.465 & -4.16 \\
\hline 1999 & -28.664 & -7.47 & -22.626 & -4.07 \\
\hline 2000 & -27.761 & -7.17 & -21.825 & -3.87 \\
\hline 2001 & -23.569 & -6.07 & -19.219 & -3.40 \\
\hline 2002 & -21.408 & -5.50 & -21.543 & -3.80 \\
\hline 2003 & -19.847 & -4.95 & -14.523 & -2.44 \\
\hline 2004 & -17.436 & -4.29 & -5.376 & -0.78 \\
\hline 2005 & -14.158 & -3.34 & -8.690 & -1.28 \\
\hline 2006 & -10.386 & -2.36 & -17.404 & -2.87 \\
\hline 2007 & -9.084 & -1.89 & 2.660 & \\
\hline 2008 & -3.717 & -0.67 & -9.214 & -1.13 \\
\hline Stock owner & -0.447 & -2.77 & -0.886 & -2.08 \\
\hline Unanticipated equity gain (millions) & -0.392 & -0.70 & -1.870 & -2.91 \\
\hline Net worth (millions) & -1.720 & -4.67 & 0.798 & 2.40 \\
\hline Ratio of net worth to income & 0.002 & 1.26 & -0.012 & -2.24 \\
\hline Has DB plan & -0.868 & -5.12 & -3.267 & -5.15 \\
\hline Male & 0.334 & 1.93 & 0.630 & 1.89 \\
\hline \multicolumn{5}{|l|}{ Education } \\
\hline High school graduate & 0.269 & 1.39 & 0.897 & 2.09 \\
\hline Some college & 0.885 & 3.56 & 2.256 & 5.18 \\
\hline College graduate & 0.707 & 2.45 & 0.442 & 0.62 \\
\hline Some graduate school & 0.988 & 3.67 & 1.940 & 3.93 \\
\hline \multicolumn{5}{|l|}{ Health } \\
\hline Excellent & 1.417 & 2.71 & 2.352 & 1.90 \\
\hline Very good & 1.439 & 2.76 & 3.075 & 2.25 \\
\hline Good & 1.609 & 3.12 & 2.845 & 2.28 \\
\hline Fair & 1.065 & 2.01 & 2.154 & 1.69 \\
\hline
\end{tabular}


Results by Employment Status

Dependent variable: retirement year (continued)

\begin{tabular}{|c|c|c|c|c|}
\hline \multirow[b]{2}{*}{ Variable Name } & \multicolumn{2}{|c|}{ Wage and Salary Workers } & \multicolumn{2}{|c|}{ Self-Employed } \\
\hline & $\begin{array}{c}\text { Marginal } \\
\text { Effect }\end{array}$ & T-Statistic & $\begin{array}{c}\text { Marginal } \\
\text { Effect }\end{array}$ & T-Statistic \\
\hline \multicolumn{5}{|l|}{ Employer-provided health insurance } \\
\hline $\mathrm{R}$ covers self and spouse & 0.843 & 3.13 & 1.608 & 3.46 \\
\hline $\mathrm{R}$ covers self only & 0.886 & 3.28 & 0.890 & 1.49 \\
\hline $\mathrm{R}$ covered by spouse & 0.588 & 1.97 & 1.508 & 2.79 \\
\hline $\mathrm{R}$ has coverage through both self and spouse & 1.650 & 4.25 & 0.435 & 0.43 \\
\hline $\begin{array}{l}\mathrm{R} \text { has retiree health insurance through self or } \\
\text { spouse }\end{array}$ & -0.817 & -4.01 & -0.438 & -0.99 \\
\hline \multicolumn{5}{|l|}{ Marital Status } \\
\hline Divorced or separated & 1.169 & 2.10 & -2.016 & -1.22 \\
\hline Widowed & 1.520 & 2.66 & 1.286 & 0.86 \\
\hline Married & 2.021 & 3.45 & 2.217 & 1.53 \\
\hline \multicolumn{5}{|l|}{ Offered early out } \\
\hline between 1992 and 1994 & -0.445 & -1.93 & 0.341 & 0.41 \\
\hline between 1994 and 1996 & -0.082 & -0.20 & 1.106 & 1.13 \\
\hline between 1996 and 1998 & 0.450 & 1.00 & -2.680 & -2.08 \\
\hline \multicolumn{5}{|l|}{ Change in marital status $1992-2000$} \\
\hline ever divorced & 0.996 & 2.13 & 1.373 & 0.85 \\
\hline ever widowed & 0.716 & 2.46 & -2.500 & -2.61 \\
\hline ever married & -0.742 & -0.97 & -0.021 & -0.02 \\
\hline \multicolumn{5}{|l|}{ Health shock } \\
\hline between 1992 and 1994 & -0.719 & -2.23 & -0.975 & -1.37 \\
\hline between 1994 and 1996 & -0.658 & -1.88 & -1.283 & -1.06 \\
\hline between 1996 and 1998 & -0.026 & -0.10 & -1.669 & -1.81 \\
\hline between 1998 and 2000 & -0.594 & -2.66 & -0.892 & -1.78 \\
\hline Health ever deteriorated from wave to wave & -0.378 & -2.38 & -0.084 & -0.23 \\
\hline Spouse's health deteriorated wave to wave & 0.032 & 0.20 & 0.381 & 1.06 \\
\hline Spouse ever had health shock & -0.176 & -0.95 & -0.393 & -0.92 \\
\hline Spouse retired between 1992 and 2000 & -0.632 & -4.01 & -1.776 & -4.59 \\
\hline
\end{tabular}

